\title{
VARIATIONS AND MODIFICATIONS OF FAR-FAMED PECTORALIS MAJOR FLAP: A REVIEW OF LITERATURE
}

\section{Rinsha Gireesh*}

\section{Shameekcha} Mishra

\section{Gaurav D} Dhanawat
MDS Oral And Maxillofacial Surgeon Rajiv Gandhi University Of Health Sciences ${ }^{*}$ Corresponding Author

MDS Oral And Maxillofacial Surgeon Rajiv Gandhi University Of Health Sciences

MDS Oral And Maxillofacial Surgeon Rajiv Gandhi University Of Health Sciences

ABSTRACT The pectoralis major flap is undoubtedly a workhorse flap in the field of head and neck oncology even with the advent of free flaps. Lack of expertise and resources limits the use of free flap and still makes pectoralis major flap widely chosen. Head and neck cancer in advanced stage requires extensive resection entailing reconstruction of various sized defects which is possible only with a versatile flap. This flap is also a salvage flap when all the other options Fails, since four decades. The purpose of this article is to highlight variations and modifications related to pectoralis major flap in head and neck reconstructive procedures. For this a thorough literature search was done using Medline and PubMed databases. Non-English language papers were excluded from the review. A total of 50 articles were obtained through verification of the title and abstract. Considering the relevance of the matter 32 articles were opted for the present review.

\section{KEYWORDS : Pectoralis, Head and Neck Cancer, Reconstructive, Flap}

\section{INTRODUCTION}

The pectoralis major flap is one of the most versatile and reliable reconstructive options for the various sub sites in head and neck region post oncological resection. Hueston and McConchie in 1968 described pectoral flap as rotational flap to repair sternal defect ${ }^{1}$. Later Brown et al. (1977) described island muscular flap based on the thoracic branch of the thoracoacromial artery to repair a defect in the anterior chest wall ${ }^{2}$. In 1979, Ariyan and Stephan were the first to describe its use for head and neck reconstruction ${ }^{3}$. Further Green and colleagues described the reconstruction of mandible using PMMC flap along with part of the sternum ${ }^{4}$. The use of costochondral segment with a PMMC flap for mandibular segmental reconstructions was described thereafter by Ariyan and Cuono ${ }^{5}$. There are lot of variations and refinements happening since then to best suit the needs. Abundant soft tissue bulk, reliable vascularity and ease of harvesting make this flap versatile. Also, it doesn't require repositioning of the patient while harvesting.

\section{Anatomy and variations}

The pectoralis major is a large fan-shaped muscle that overlies the pectoralis minor, subclavius, serratus anterior, intercostal muscles and covers the anterior chest wall. The origins of this muscle can be divided into three; the cephalad segment arising from the medial third of the clavicle.The sternocostal, originating from the sternum and the cartilages of the first six ribs and the third segment originating from the aponeurosis of the external oblique muscle. The muscle converges to form a tendon that passes deep to the deltoid and inserts into the crest of the greater tubercle of the humerus forming axillary fold. The pectoralis major is closely associated with the medial aspect of the deltoid muscle, forming the deltopectoral groove, which contains the constant anatomical landmark, cephalic vein. There are few reported variations from this normal anatomy.

Robert et al. in their study observed fusion between the clavicular portion of pectoralis and the deltoid muscle, the deltopectoral groove was absent, also the brachial segment of the cephalic vein was absent bilaterally ${ }^{6}$. Similarly, Natsis et al. described complete fusion between the pectoralis major and the deltoid muscles, with absence of deltopectoral groove and the infraclavicular fossa ${ }^{7}$.
Bala and colleagues noticed unilateral absence of sternocostal fibers of pectoralis major muscle with presence of sternalis muscle ${ }^{8}$. This muscle, a rare presentation, covers the medial border of the pectoralis major and runs parallel to the sternum, extending from the jugular notch to the Costal region. Sternalis, if present may be mistaken for a malignancy on mammography or CT scan ${ }^{9}$. Although, the incidence reported is approximately $4.4-11.5 \%{ }^{10}$.

Atypical division of pectoralis muscle into two almost completely separate portions was described by Robert et al. ${ }^{6}$ And, in 1871 Perrin reported clavicular portion of the muscle divided into two slips, few centimetres from its distal attachment. Besides, he also mentioned three other variations including epigastric slips, muscular or musculo-tendinous or entirely tendinous slips from the latissimus dorsi and varieties of the chondro-epitrochlearis muscle ${ }^{11}$. Apart from this Patil et al mentioned about accessory muscle originating from the lower part of the outer surface of 4 th rib about $3-4 \mathrm{~cm}$ distal to costochondral junction and fused with the deep surface of pectoralis major muscle near its insertion ${ }^{12}$.

\section{Variations in vascularity}

The pectoralis major is a Mathes and Nahai type V muscle with one major vascular pedicle from the thoracoacromial artery and secondary segmental parasternal perforators that arise medially from the internal mammary artery. The lateral thoracic artery, although it is not thought to contribute significantly to the blood supply of the muscle, is often sacrificed to improve the arc of rotation of the muscle. In the study by Moloy and Gonzales, 24 cases revealed that the lateral thoracic artery and pectoral branch of the thoracoacromial artery are of equal calibre and 8 cases demonstrated it to be larger in diameter. In such cases if circulation through the thoracoacromial artery is poor or nonexistent, the flap should be pedicled on both the arterie ${ }^{13}$.

\section{Flap design}

Being the most versatile flap, it is also known as a workhorse flap in reconstructive surgery. The major advantages include rich vascularity, large skin territory of around $400 \mathrm{~cm}^{2}$, ability to transfer without prior delay, improved arc of rotation, increased bulk, well vascularized tissue coverage of carotid artery in the event of a salivary fistula or cervical skin necrosis, ease of harvest in supine position and primary donor site 
closure, to name a few ${ }^{14}$. Several skin paddle designs have been described in literature based on the location. Among them inferiorly located inframammary skin paddle design is especially important in females as it preserves breast symmetry and is more aesthetic. The medial skin paddle designs can be categorized as elliptical, bilenticular, parallelogram, rhomboid, irregular, and crescenteric. There are two elliptical variations: (1) curving around the nipple to avoid placement of the skin paddle over the rectus abdominis muscle as described by Liu et al. and (2) medial to the nipple and overlying the xiphoid as originally described by Ariyan. Similarly, Sasaki et al. introduced the sickle-shaped skin paddle placed medially and including the cutaneous territory below the nipple.

The extended pectoralis major flap with skin paddle extended caudally by including the rectus fascia, down to the periumbilical region owing to a rich vascular network anastomosing with the superior epigastric system is one of the flap design described by Magee et al. Other designs include pectoralis major double- paddle modification providing two epithelial surfaces side-by-side. And Fleischer and Khafif described tubed PMMC to reconstruct trachea following total laryngectomy and tracheal resection for a recurrent thyroid carcinoma. Here, one end of the pectoralis skin tube was sutured to the trachea and the other end was sutured to the skin, creating a new stoma ${ }^{15}$.

\section{Modifications timeline}

Pectoralis major with all the given modifications is a reliable and practical option for the reconstruction of soft tissue defects. There are various modifications described in the literature since its first mention. (Table 1)

\begin{tabular}{|c|c|c|c|c|c|c|}
\hline $\begin{array}{l}\text { Author/ } \\
\text { article Name }\end{array}$ & Year & Design & $\begin{array}{l}\text { Site Of The } \\
\text { Defect }\end{array}$ & \begin{tabular}{|l} 
Sample \\
Size
\end{tabular} & Outcome & Complication \\
\hline $\begin{array}{l}\text { Donegan et } \\
\text { al., }{ }^{16}\end{array}$ & 1981 & $\begin{array}{l}\text {-Approach to PMMC via elevation } \\
\text { of DP flap }\end{array}$ & $\begin{array}{l}\text { Mucosal and } \\
\text { cutaneous } \\
\text { lesions of head } \\
\text { and neck }\end{array}$ & 16 & \begin{tabular}{|l|}
-Preservation of \\
ipsilateral DP flap. \\
-Better exposure of \\
donor area. \\
-Ease of identification of \\
vascular pedicle.
\end{tabular} & \\
\hline Krespi et al., ${ }^{17}$ & 1982 & \begin{tabular}{|l}
-Circumferential incision \\
-Division of lateral border of \\
pectoralis minor muscle
\end{tabular} & - & - & $\begin{array}{l}\text {-Additional gain in } \\
\text { length of flap by } 3-5 \mathrm{~cm} \text {. }\end{array}$ & \\
\hline $\begin{array}{l}\text { Gordon R } \\
\text { Tobin }^{18}\end{array}$ & 1984 & $\begin{array}{l}\text {-Segmental division technique } \\
\text { (pectoralis major muscle) } \\
-3 \text { independent segments } \\
\text { (clavicular, sternocostal and } \\
\text { external) based on vascular } \\
\text { territory }\end{array}$ & $\begin{array}{l}\text {-head and neck, } \\
\text { chest wall and } \\
\text { upper extremity } \\
\text { defect }\end{array}$ & \begin{tabular}{|l|}
-105 \\
cadavers \\
-36 \\
clinical \\
reconstruc \\
tion
\end{tabular} & $\begin{array}{l}\text {-Leaving innervated } \\
\text { muscle segment in situ. } \\
\text {-Preserve motor function. } \\
\text {-Deriving } 2 \text { independent } \\
\text { flaps from one muscle. }\end{array}$ & $\begin{array}{l}\text {-Minor loss of } \\
\text { most distal } \\
\text { portion of } \\
\text { flap. }\end{array}$ \\
\hline $\begin{array}{l}\text { Robertson et } \\
\mathrm{al}^{19}\end{array}$ & 1985 & $\begin{array}{l}\text {-Skin-Grafted Pectoralis Major } \\
\text { Muscle Flaps }\end{array}$ & $\begin{array}{l}\text { Partial } \\
\text { pharyngeal } \\
\text { replacement }\end{array}$ & 6 & $\begin{array}{l}\text {-No strictures at the } \\
\text { pharyngoesophageal } \\
\text { junction. } \\
\text {-Established a good oral } \\
\text { intake. }\end{array}$ & $\begin{array}{l}\text {-Pharyngo- } \\
\text { cutaneous } \\
\text { fistula. }\end{array}$ \\
\hline $\begin{array}{l}\text { De Azevedo } \\
\text { J.F. }^{2}\end{array}$ & 1986 & $\begin{array}{l}\text {-Modified pectoralis major } \\
\text { myocutaneous flap with partial } \\
\text { preservation of the muscle. } \\
\text { The clavicular bundles, the first two } \\
\text { or three sternocostal bundles, and } \\
\text { the lateral border of the muscle } \\
\text { were preserved }\end{array}$ & $\begin{array}{l}\text { Reconstruction of } \\
\text { head and neck } \\
\text { defects }\end{array}$ & 55 & $\begin{array}{l}\text {-No functional sequelae } \\
\text { of the arm, visible } \\
\text { depressions in the } \\
\text { infraclavicular area, or } \\
\text { loss of the anatomic } \\
\text { configuration of the } \\
\text { anterior axillary line. }\end{array}$ & $\begin{array}{l}\text {-One case of } \\
\text { flap } \\
\text { necrosis. } \\
\text {-Ten cases of } \\
\text { Muscle } \\
\text { atrophy. }\end{array}$ \\
\hline $\begin{array}{l}\text { Colman et } \\
\text { al., }^{20}\end{array}$ & 1986 & $\begin{array}{l}\text {-Modification of PMMC design in } \\
\text { women by giving a C-shaped } \\
\text { incision }\end{array}$ & & & $\begin{array}{l}\text {-Esthetically pleasing by } \\
\text { maintaining near } \\
\text { normal breast contour. }\end{array}$ & \\
\hline $\begin{array}{l}\text { Phillips et } \\
\text { al., }\end{array}$ & 1988 & $\begin{array}{l}\text {-PMMF flap without skin in intra- } \\
\text { oral reconstruction }\end{array}$ & -oral cancer & 3 & $\begin{array}{l}\text {-Easy. } \\
\text {-Mucosalisation of } \\
\text { intraoral tissues is } \\
\text { faster. } \\
\text {-Return of function better } \\
\text { than myocutaneous flap. } \\
\text {-Minimal breast } \\
\text { changes. } \\
\text {-Avoids problem of hair } \\
\text { growth }\end{array}$ & $\begin{array}{l}\text {-Atrophy of } \\
\text { flap due to } \\
\text { denervation. }\end{array}$ \\
\hline Marx et al., & 1990 & $\begin{array}{l}\text {-Curvilinear incision placed medial } \\
\text { to nipple } \\
\text {-Extremely useful in stage III cases } \\
\text { of ORN. } \\
\text {-Preserves all three axial blood } \\
\text { supply. } \\
\text {-Entire muscle raised in developing } \\
\text { the flap }\end{array}$ & $\begin{array}{l}\text { 19- oral } \\
\text { Defects } \\
20 \text { - } \\
\text { submandibular } \\
20 \text {-floor } \\
\text { Of mouth } \\
11 \text {-external chin } \\
2 \text {-buccal mucosa } \\
\text { 5-sub } \\
\text {-mental area } \\
\text { defects }\end{array}$ & 54 & \begin{tabular}{|l|}
-More predictable \\
transfer of tissue in even \\
heavily irradiated areas. \\
-Less complication and \\
less residual \\
deficiencies. \\
-Cosmetically \\
acceptable.
\end{tabular} & $\begin{array}{l}\text { Partial } \\
\text { necrosis of } \\
\text { the skin } \\
\text { paddle }\end{array}$ \\
\hline
\end{tabular}




\begin{tabular}{|c|c|c|c|c|c|c|}
\hline $\begin{array}{l}\text { Espinosa et } \\
\text { al., }{ }^{23}\end{array}$ & 1992 & $\begin{array}{l}\text {-Horizontal double skin island } \\
\text { PMMC with nipple-areola complex } \\
\text { preservation-modified }\end{array}$ & \begin{tabular}{|l}
-Gingival \\
carcinoma
\end{tabular} & 1 & \begin{tabular}{|l|}
-Provides tissue for \\
immediate \\
reconstruction of both \\
mucosal and skin lining.
\end{tabular} & \\
\hline Kasler et al.,. ${ }^{24}$ & & $\begin{array}{l}\text { Bilobular flap. } \\
\text {-The muscle between the skin islands } \\
\text { provides the soft tissue bulk between } \\
\text { the internal mucosal and external } \\
\text { skin lining }\end{array}$ & $\begin{array}{l}\text {-Gingival } \\
\text { carcinoma }\end{array}$ & & \begin{tabular}{|l|}
-Enough bulk. \\
-Achieves good aesthetic \\
and functional result. \\
-Allows the patient to \\
receive adjuvant \\
treatment without undue \\
delay. \\
-Allows the patient to \\
return to society within a \\
reasonable period of \\
time
\end{tabular} & \\
\hline $\begin{array}{l}\text { Schreiber et } \\
\text { al., }^{25}\end{array}$ & 1992 & $\begin{array}{l}\text {-Seldinger's selective trans femoral } \\
\text { method was used for pre-operative } \\
\text { angiographic studies of the } \\
\text { subclavian artery in } 18 \text { cases to } \\
\text { determine the exact position of the } \\
\text { thoracoacromial artery } \\
\text { - During the preparation of the } \\
\text { pedicle, the muscle fibres were not } \\
\text { cut }\end{array}$ & $\begin{array}{l}\text { 33-oral defects } \\
\text { 23-oropharyngeal } \\
\text { defects } \\
\text { 18-hypopharyngeal } \\
\text { defects extending to } \\
\text { larynx }\end{array}$ & 75 & $\begin{array}{l}\text {-Possible to bridge } \\
\text { substantial distances } \\
\text { between the donor site } \\
\text { and the defect caused } \\
\text { by removal of the } \\
\text { primary tumour. } \\
\text {-Tonsil lingual and soft } \\
\text { palate defects can also } \\
\text { be closed. }\end{array}$ & \begin{tabular}{|l|}
-3 cases of \\
partial \\
necrosis. \\
-13 cases of \\
post-operative \\
fistulas.
\end{tabular} \\
\hline Chen et $\alpha l^{26}$ & 2004 & $\begin{array}{l}\text {-Anomalous pathway of pectoral } \\
\text { branch of thoracoacromial artery } \\
\text { entering through the pectoralis } \\
\text { minor muscle. } \\
\text {-the flap was raised along with the } \\
\text { pectoralis minor muscle }\end{array}$ & $\begin{array}{l}\text { Metastaic merkel } \\
\text { cell tumor of neck. }\end{array}$ & - & -Greater pedicle length. & \\
\hline $\begin{array}{l}\text { Espitalier et } \\
\text { al. }^{27}\end{array}$ & 2009 & -Bilobed flap & $\begin{array}{l}\text { Reconstruction of } \\
\text { intra-oral defects }\end{array}$ & 8 & $\begin{array}{l}\text {-Appearance and } \\
\text { function satisfactory. } \\
\text {-All the flaps survived. }\end{array}$ & \\
\hline $\begin{array}{l}\text { Yukiko nishi } \\
\text { et } \mathrm{al}^{28}\end{array}$ & 2012 & $\begin{array}{l}\text {-U-shaped pectoralis major } \\
\text { myocutaneous flap }\end{array}$ & $\begin{array}{l}\text { Reconstruction of } \\
\text { the hypopharynx } \\
\text { after } \\
\text { circumferential } \\
\text { pharyngolaryngect } \\
\text { omy }\end{array}$ & 41 & $\begin{array}{l}\text {-Simple, reliable, and } \\
\text { allows adequate } \\
\text { reconstruction of the } \\
\text { hypopharynx }\end{array}$ & \begin{tabular}{|l|}
-Neopharynx \\
-Stricture rate \\
is high. \\
-Quality of \\
voice \\
rehabilitation \\
is poor.
\end{tabular} \\
\hline Kanno et $a .^{29}$ & 2013 & $\begin{array}{l}\text {-Pectoral Perforator flap } \\
\text {-Including the muscular branch of } \\
\text { the second and third intercostal } \\
\text { branches and the pectoral branch of } \\
\text { the thoracoacromial artery }\end{array}$ & $\begin{array}{l}\text { - Tongue cancer } \\
\text { 1- Floor of mouth } \\
\text { defects } \\
\text { 2- Skin defects in } \\
\text { the lower portion of } \\
\text { the pinna }\end{array}$ & 6 & $\begin{array}{l}\text {-Pectoral Perforator flap } \\
\text { does not contain in its } \\
\text { skin paddle the } \\
\text { pectoralis major muscle } \\
\text { and the mammary } \\
\text { gland, making it } \\
\text { possible to produce a } \\
\text { thin flap. } \\
\text {-Satisfactory, functional, } \\
\text { good cosmetic results. } \\
\text {-Extended length. }\end{array}$ & - \\
\hline $\begin{array}{l}\text { Eugene et } \\
\mathrm{al} .^{30}\end{array}$ & 2015 & $\begin{array}{l}\text { - Preserving the lateral thoracic } \\
\text { vessels } \\
\text {-PMMC flap was transferred via } \\
\text { subclavian route which improved the } \\
\text { arc of rotation }\end{array}$ & -Oral cancer & 1 & $\begin{array}{l}\text {-Improved blood supply } \\
\text { to the distal PMMC flap } \\
\text { and increase its rotation } \\
\text { arc. }\end{array}$ & - \\
\hline $\begin{array}{l}\text { Pancholi et } \\
\text { al., }{ }^{31}\end{array}$ & 2016 & $\begin{array}{l}\text {-Extending arc of rotation by passing } \\
\text { the flap through modified } \\
\text { subclavicular route through } \\
\text { clavipectoral fascia. }\end{array}$ & \begin{tabular}{|l|} 
- Gingival \\
carcinoma \\
2-FOM \\
2-Tongue \\
carcinoma \\
1-RMT and soft \\
palatel- \\
Cervicoesophageal \\
carcinoma
\end{tabular} & 12 & $\begin{array}{l}\text {-Increased cephalad } \\
\text { extension of flap by } \\
\text { gaining additional } \\
\text { length. }\end{array}$ & \begin{tabular}{|l|}
-Transient \\
venous \\
congestion \\
-Wound \\
dehiscence \\
-Orocutaneous \\
fistula.
\end{tabular} \\
\hline
\end{tabular}




\begin{tabular}{|c|c|c|c|c|c|c|}
\hline \multirow[t]{3}{*}{$\begin{array}{l}\text { Raunchenwal } \\
\text { d et al. }{ }^{32}\end{array}$} & 2019 & $\begin{array}{l}\text { - Crossed pectoralis major } \\
\text { myocutaneous flap } \\
\text {-Contralateral Pectoralis Major } \\
\text { Myocutaneous Flap }\end{array}$ & $\begin{array}{l}\text {-recurrent oral } \\
\text { cancer of } \\
\text { buccal mucosa }\end{array}$ & 5 & $\begin{array}{l}\text {-Mucosal and skin } \\
\text { defect can be covered. } \\
\text {-Suitable in post } \\
\text { irradiated patients. } \\
\text {-No prolongation of } \\
\text { waiting period after } \\
\text { completing surgical } \\
\text { treatment }\end{array}$ & $\begin{array}{l}\text {-Minor } \\
\text { seroma } \\
\text { formation } \\
\text { and suture } \\
\text { dehiscence. }\end{array}$ \\
\hline & 2019 & $\begin{array}{l}\text {-Modified surgical technique to } \\
\text { harvests the pectoralis major muscle } \\
\text { as an island flap } \\
\text {-Muscle sparing approach. } \\
\text {-Can be used as both }\end{array}$ & $\begin{array}{l}\text { 19-Carcinoma } \\
\text { of larynx } \\
\text { 4-Carcinoma of } \\
\text { pharynx }\end{array}$ & 23 & $\begin{array}{l}\text {-Mean operative time } \\
\text { was shorter ( } 2 \mathrm{hrs} .) \\
\text { compared to } \\
\text { microvascular tissue } \\
\text { transfer. }\end{array}$ & $\begin{array}{l}\text {-Long term } \\
\text { follow up to } \\
\text { be done to } \\
\text { see the } \\
\text { outcome. }\end{array}$ \\
\hline & & myocutaneous and muscle only flap. & & & \begin{tabular}{|l}
-Decreased donor site \\
morbidity by sparing \\
clavicular and superior \\
sternocostal part of \\
muscle which is involved \\
in internal rotation. \\
-Improved aesthetic \\
because of minimal \\
incision lines.
\end{tabular} & \\
\hline
\end{tabular}

PMMC - Pectoralis major myocutaneous flap; DP Deltopectoral flap; ORN - Osteoradionecrosis, FOM-Floor of mouth;RMT-Retromolar trigone;PMMF-Pectoralis major myocutaneous flap

\section{CONCLUSION}

Pectoralis major flap is one of the most versatile and reliable reconstructive option for the various subsites in the head and neck region. Given the outcomes achieved despite several modifications it has undergone since its inception, proves the versatility of the flap.Above mentioned table throws light on various permutations and combinations of the flap which can be utilized in different situations with advantageous outcome. The understanding of its anatomy and variation would help surgeon to use it safely in the setup where financial, structural and lack of instruments and other facilities for free flap is not available post oncological resections.

\section{REFERENCES}

[1] Hueston, J. T., \& McConchte, I. H. (1968). A compound pectoral flap. Australian and New Zealand Journal of Surgery, 38(1), 61-63.

[2] de Azevedo, J. F. (1986). Modified pectoralis major myocutaneous flap with partial preservation of the muscle: a study of 55 cases. Head \& neck surgery, 8(5), 327-331.

[3] Ariyan, S. (1979). The pectoralis major myocutaneous flap. Plast Reconstr Surg, 63(1), 73-81.

[4] Green, M. F., Gibson, J. R., Bryson, J. R., \& Thomson, E. (1981). A one-stage correction of mandibular defects using a split sternum pectoralis major osteomusculocutaneous transfer. British Journal of Plastic Surgery, 34(1), 11-16.

[5] Cuono, C. B., \& Ariyan, S. (1980). Immediate reconstruction of a composite mandibular defect with a regional osteomusculocutaneous flap. Plastic and reconstructive surgery, 65(4), 477-484.

[6] Haładaj, R., Wysiadecki, G., Clarke, E., Polguj, M., \& Topol, M. (2019). Anatomical Variations of the Pectoralis Major Muscle: Notes on Their Impact on Pectoral Nerve Innervation Patterns and Discussion on Their Clinical Relevance. BioMed research international, 2019

[7] Natsis, K., Tsakotos, G., Vlasis, K., Totlis, T., \& Jurgen, K. (2011). Absence of the deltopectoral groove. ANZ journal of surgery, 81 (3), 204

[8] Bala, M., Passi, D. K., \& Kaushal, S. (2014). The pectoral-sternalis complex: an unusual case report. Journal of Morphological Sciences, 31(04), 241-243.

[9] Kitamura, S., Yoshioka, T., Kaneda, M., Matsuoka, K., Chen, K. L., \& Sakai, A. (1985). A case of the congenital partial defect of the pectoralis majoraccompanied by the sternalis with enormous size. Kaibogaku zasshi. Journal of anatomy, 60(6), 728 .

[10] Ram, D., Selvakumar, V. P., \& Sharma, K. (2018). Sternalis Muscle: Not So Uncommon Entity. Indian journal of surgical oncology, 9(2), 280-281.

[11] Perrin, J. B. (1871). Notes on some variations of the pectoralis major, with its associate muscles. Journal of anatomy and physiology, 5(Pt 2), 233

[12] Patil, Jyothsna, et al. "Accessory Pectoralis Muscle Intervening Between Pectoralis Major and Minor Muscles-A Case Report." International Journal of Health Sciences and Research 4.2 (2014): 198-201.

[13] Moloy, P. J., \& Gonzales, F. E. (1986). Vascular anatomy of the pectoralis major myocutaneous flap. Archives of Otolaryngology-Head \& Neck Surgery, $112(1), 66-69$

[14] Urken, M. L., Cheney, M. L., Blackwell, K. E., Harris, J. R., Hadlock, T. A., \& Futran, N. (2012). Atlas of regional and free flaps for head and neck reconstruction: flap harvest and insetting. Lippincott Williams \& Wilkins.

[15] Teo, K. G., Rozen, W. M., \& Acosta, R. (2013). The pectoralis major myocutaneous flap. Journal of reconstructive microsurgery, 29(07), 449-456.
[16] Donegan, J. O, Whiteley, J. Gluckman, J. L. \& Shumrick, D. A. (1981) Improved method of harvesting the pectoralis major myocutaneous flap. American journal of otolaryngology، 2(3), 223-227.

[17] Krespi, Y. P., Wurster, C. F., \& Sisson, G. A. (1983). Head and neck and plastic surgery: a longer muscle pedicle for pectoralis myocutaneous flap. The Laryngoscope, 93(10), 1360-1361.

[18] Tobin, G. R. (1985). Pectoralis major segmental anatomy and segmentally split pectoralis major flaps. Plastic and reconstructive surgery, 75(6), 814-824.

[19] Robertson, M. S., \& Robinson, J. M. (1985). Pharyngoesophageal reconstruction: Is a skin-lined pharynx necessary?. Archives of Otolaryngology, 111 (6), 375-376.

[20] Colman, M. F., \& Zemplenyi, J. (1986). Head and neck and plastic surgery design of incisions for pectoralis myocutaneous flaps in women. The Laryngoscope, 96(6), 695-696.

[21] Phillips, J. G., Postlethwaite, K., \& Peckitt, N. (1988). The pectoralis major muscle flap without skin in intra-oral reconstruction. British Journal of Oral and Maxillofacial Surgery, 26(6), 479-485.

[22] Marx, R. E., \& Smith, B. R. (1990). An improved technique for development of the pectoralis major myocutaneous flap. Journal of oral and maxillofacial surgery, 48(11), 1168-1180.

[23] Espinosa, M. H., Phillip, J. A., Khatri, V. P., \& Amin, A. K. (1992). Double skin island pectoralis major myocutaneous flap with nipple-areola complex preservation: A case report. Head \& neck, 14(6), 488-491.

[24] Kasler, M., Banhidy, F. G., \& Trizna, Z. (1992). Experience with the modified pectoralis major myocutaneous flap. Archives of Otolaryngology-Head \& Neck Surgery, 118(9), 931-932.

[25] Schreiber, J. E., \& Didolkar, M. S. (2004). An alternate pedicle to the pectoralis major myocutaneous flap. Plastic and reconstructive surgery, 114(3), 814-815.

[26] Chen, S., Li, W., Wang, Q., \& Zhang, S. (2009). Experience of the pectoralis major myocutaneous island flap in simultaneous reconstruction of defects after the resection of oral carcinoma. International Journal of Oral and Maxillofacial Surgery, 38(5), 582-583.

[27] Espitalier, F., Ferron, C., Leux, C., Jégoux, F., Durand, N., Beauvillain de Montreuil, C., \& Malard, O. (2012). Results after u-shaped pectoralis major myocutaneous flap reconstruction of circumferential pharyngeal defects. The Laryngoscope, 122(12), 2677-2682.

[28] Nishi, Y., Rikimaru, H., Kiyokawa, K., Watanabe, K., Koga, N., \& Sakamoto, A. (2013). Development of the pectoral perforator flap and the deltopectoral perforator flap pedicled with the pectoralis major muscle flap. Annals of plastic surgery, $71(4), 365-371$.

[29] Kanno, T., Nariai, Y., Tatsumi, H., Karino, M., Yoshino, A., \& Sekine, J. (2015) . A modified pectoralis major myocutaneous flap technique with improved vascular supply and an extended rotation arc for oral defects: A case report. Oncology letters, 10(5), 2739-2742.

[30] Poh, E. H. K., Xu, L. Q., Yin, X. L., \& Shen, S. K. (2017). Extending the arc of rotation of the pectoralis major myocutaneous flap for orofacial reconstruction via a modified subclavicular route through the clavipectoral fascia. Journal of Oral and Maxillofacial Surgery, 75(1), 222-el.

[31] Pancholi, M., Sharma, S., Desai, S. M., \& Agrawal, D. (2016). Crossed pectoralis major myocutaneous flap for recurrent oral cavity cancers. Annals of maxillofacial surgery, 6(2), 219.

[32] Rauchenwald, T., Dejaco, D., Morandi, E. M., Djedovic, G., Wolfram, D. Riechelmann, H., \& Pierer, G. (2019). The Pectoralis Major Island Flap: Shor Scar Modified Muscle-Sparing Harvesting Technique Improves Aesthetic Outcome in Reconstructive Head and Neck Surgery. ORL, 81 (5-6), 327-337. 